\title{
Can Capital Punishment Survive if Black Lives Matter?
}

\author{
Michael Cholbi
}

Alex Madva

The Black Lives Matter protests, and the broader Movement for Black Lives they inspired, came to rapid prominence in no small part because their signature cause - police shootings of unarmed or unthreatening Black Americans — is perversely telegenic and (for most Americans) jarring. The grainy web videos depicting confrontations between police and Black citizens, nearly always ending with a Black citizen crumpled over, brought attention to a phenomenon that had previously received sporadic attention outside Black communities.

However, other causes advocated by the Movement are more familiar and (at least in the context of American judicial and legal history) prosaic. For instance, the Movement's platform calls for the abolition of capital punishment on the grounds that the death penalty in the U.S. is a "racist practice" that "devalues Black lives" (Movement for Black Lives 2017). ${ }^{1}$ In so doing, the Movement refers to a body of empirical studies (dating back to the 1940's; Myrdal 1944) suggesting racial discrimination in the administration of the death penalty in the United States. More specifically, these studies indicate both that Black American capital defendants are more likely to be subject to execution than defendants of other races and that those who murder Black Americans are less likely to be subject to execution than are those who murder members of other races. The question of whether such apparent discrimination legally impugns the death penalty

\footnotetext{
${ }^{1}$ We first explored philosophical questions based on the Movement's claims about the death penalty in Cholbi and Madva (2018). See also Cholbi (2006).
} 
has a long legal history in the U.S., and in general, while the courts have occasionally expressed worries about such discrimination, jurists have taken such evidence to warrant reform of capital punishment practices but not its outright abolition. In calling for abolition, the Movement thus invites us to see the death penalty as one among many fronts in a "war against Black people" and "Black communities" in the United States (Movement for Black Lives 2017).

Our purpose here is to defend the Movement's call for death penalty abolition on grounds that (we expect) those sympathetic to the Movement's diagnosis of the current state of racial justice in the United State will find congenial. We do so first by providing a sketch of recent American judiciary history surrounding race and capital punishment, a sketch that reveals how the forms of bias essential for understanding how racial discrimination in the American capital punishment regime occurs do not fit within the picture of racial bias advanced by the courts. The racial discrimination at issue, we argue, flows in significant part from implicit biases concerning race, criminality, and violence. That implicit biases play such a role explains both why recent capital sentencing reforms have been largely unsuccessful in diminishing such discrimination and why further procedural reforms aimed at reducing such discrimination should also be met with skepticism. We then turn to the case for abolition as a response to this persistent discrimination. Defenders of capital punishment have not fully appreciated that such discrimination grounds a complaint on the part not only of those Black Americans who interact with the criminal justice system as capital defendants or as murder victims, but also on the part of Black Americans as a class who have not been accorded equal status under the law. The magnitude of this latter complaint, we argue, along with the intractability of this discrimination make abolition a compelling remedy. The time for abolition of the death penalty has therefore 
arrived, as it is the most efficacious and most just response to the realities surrounding race and capital punishment in the U.S.. ${ }^{2}$

$* * * * * * * * * * * * * * * * * * * * * * * * * * * * * * *$

In 1972, the U.S. Supreme Court vacated the death sentences of three Black American men, William Furman, Lucius Jackson, and Elmer Branch. In each case, the applicable state laws did not provide juries with unambiguous criteria by which to determine whether a defendant should be sentenced to die. In a 5-4 vote, the Court ruled in the appellants' favor, their per curium opinion holding that the state statutes under which the defendants were convicted were unconstitutional, and so the "carrying out of the death penalty in these cases constitute cruel and unusual punishment in violation of the Eighth and Fourteenth Amendments" (Furman 1972: p, 240). This language is puzzling on its face. The Eighth Amendment seems to impose a substantive limitation on the kinds of punishment to which criminals may be subject, to wit, that those punishments not be cruel or unusual. The post-Reconstruction Fourteenth Amendment, in contrast, is concerned with legal equality, demanding that states not deny citizens the equal protection of their laws. How then could a death sentence in these cases violate both such Amendments by virtue of being "cruel and unusual"? There was little unanimity in the rationales provided by the concurring justices. (The decision itself reached an astonishing 80,000 words in total.) Justices Brennan and Marshall advanced recognizably Eighth Amendment arguments,

\footnotetext{
${ }^{2}$ In claiming that capital punishment practice in the U.S. have failed to accord Black Americans equal legal status, we acknowledge that a range of other practices (such as extra-judicial lynchings, police brutality, drug laws imposing harsher sentences for substances used to a greater degree in Black communities, etc.) have contributed to the denigration of Black Americans’ equal status as well. See James (2000) and Muhammad (2010).
} 
asserting that death was by its nature cruel and unusual, a sanction at odds with "human dignity" (Furman, 1972, p., 291) and "shocking" to the "conscience and sense of justice" of the average citizen (Furman, 1972, p. 365). (One dissenting justice, Blackmun, expressed similar sentiments: "I yield to no one in the depth of my distaste, antipathy, and, indeed, abhorrence, for the death penalty, with all its aspects of physical distress and fear and of moral judgment exercised by finite minds" (Furman, 1972, p. 405).)

What, then, of the defendants' Fourteenth Amendment complaint? Their attorneys had offered evidence that non-White defendants received the death penalty more often than Whites. Such statutes thus seemed to permit racial discrimination to influence capital sentencing, such that Black Americans did not have the same legal protection or status as other defendants. Several of the justices accepted such empirical findings, and were clearly unnerved by the prospect that capital punishment gave "room for the play of such prejudices" against "the poor and the despised," as Douglas put it (Furman, 1972, p. 255). Strangely, though, it was not concerns about racial bias that primarily moved the justices. Rather, the justices emphasized that the capital punishment statutes then in existence resulted in "unusual" punishments because they provided judges and juries too much discretion in deciding which defendants are sentenced to die. Douglas decried the "uncontrolled discretion of judges or judges" in the determination whether defendants committing these crimes should die or be imprisoned. Under these laws, no standards govern the selection of the penalty. People live or die, dependent on the whim of one man or of 12. (Furman, 1972, p. 253)

Justice Stewart denied that racial discrimination had been proven in these cases, but nonetheless concluded that death was "wantonly" and "freakishly imposed," with no more rhyme or reason than lightning strikes (Furman, 1972, p. 310). Justice White similarly complained that "there is 
no meaningful basis for distinguishing the few cases in which it [death] is imposed from the many cases in which it is not" (Furman, 1972, p. 313).

Thus, despite the race-based arguments advanced by the defendants, and despite the justices' evident dismay at the apparent racial disproportionality in capital sentencing, racial discrimination turned out to play a rather marginal role in the justices' reasoning. Their central concern was instead that the laws gave decision makers too much latitude in deciding who to sentence to die and so provided no rational basis for the allocation of the most severe punishment utilized in our legal system. This emphasis on the "freakish" or "arbitrary" imposition of the death penalty governed subsequent efforts at reforms. The Furman ruling resulted in a four-year moratorium on the death penalty in the U.S., during which time states crafted new capital punishment statutes and sentencing guidelines. New state statutes and sentencing guidelines required that both aggravating and mitigating factors be taken into account in capital sentencing; capital trials be bifurcated into guilt and penalty phases; capital cases be subject to automatic appeal; and states conduct proportionality reviews, in which a state appellate court considers whether a given capital sentence aligns with, or is instead disproportionate to, other sentences issued in the state's capital cases. In a series of cases beginning with Gregg vs. Georgia (1976; Cholbi and Madva 2018, n.8), the Supreme Court concluded that such state statutes satisfied the procedural criteria put forth in Furman: that capital sentencing be guided by objective criteria but still responsive to judge and jury determinations of particular defendants' record, character, and capital crime (i.e., the death penalty could not be automatically imposed on those convicted of a particular class of crimes). American capital punishment jurisprudence thus entered a period of "guided discretion," wherein the death penalty was permissible so long as the discretion 
exercised by judges or juries was (as the Furman ruling mandated) "suitably directed and limited so as to minimize the risk of wholly arbitrary and capricious action.”

Neither the new state sentencing guidelines nor the language of "guided discretion" explicitly mentioned racial discrimination. Yet given the concerns about racial discrimination expressed by the justices in Furman, one might expect the Court to be sympathetic to defendants claiming that their own death sentences were shaped by racial biases that, for whatever reason, the post-Furman reforms were not able to identify or mitigate. McCleskey v. Kemp (1987) tested this hypothesis. Warren McCleskey, a Black American man, was convicted of the murder of White Atlanta police officer Frank Schlatt. The jury sentenced him to die because of two aggravating circumstances: that the murder occurred during the commission of an armed robbery and his victim was a police officer engaged in performing his official duties. As in Furman, McCleskey's attorneys invoked the Fourteenth Amendment requirement of equal protection and cited studies indicating "racially disproportionate impact" in the imposition of capital punishment in Georgia. The most prominent of these studies was conducted by David Baldus, whose examination of 2,500 murder cases in Georgia found that those convicted of killing a White victim were 4.3 times as likely to receive the death penalty than those whose victims were from other racial groups (Baldus, Pulaski, and Woodworth 1983). The Court ruled against McCleskey. An equal protection finding, the Court concluded, required more than evidence of "racially disproportionate impact," for sentencing disparities of the sort highlighted in Baldus' study are "an inevitable part of our criminal justice system." McCleskey had instead to "prove" either that "the decisionmakers in his case acted with discriminatory purpose" or that the state legislature had "enacted or maintained the death penalty statute because of an anticipated racially discriminatory effect." McCleskey lacked such evidence. He was executed in 1991. 
As a number of critics of the McCleskey decision observed, the ruling sets a nearly impossible bar for claims of unconstitutional racial discrimination in sentencing. Societal opposition to overt racism, as well as the fact that many law enforcement or judicial decisions that could be influenced by race are not open to public scrutiny, makes it almost certain that "smoking gun" evidence of overt or intentional racial discrimination on the part of lawmakers, prosecutors, or law enforcement officials will not be uncovered. As Michelle Alexander, author of The New Jim Crow, has concluded:

McCleskey v. Kemp has immunized the criminal justice system from judicial scrutiny for racial bias. It has made it virtually impossible to challenge any aspect, criminal justice process, for racial bias in the absence of proof of intentional discrimination, conscious, deliberate bias ... Evidence of conscious intentional bias is almost impossible to come by in the absence of some kind of admission. (Alexander 2010)

Given the standard set by McCleskey, it is not surprising that capital defendants have had virtually no success in advancing claims of racial discrimination subsequently (aside from claims relating to the selection of jurors on the basis of race (see Batson 1986, Miller-El 2005, and Snyder 2008). This is so despite the mounting evidence that patterns of racial discrimination of the sort found in Baldus' study continue to this day. Since 2000, empirical studies of nine states have found that Black American defendants are more likely to face a death penalty prosecution or to be sentenced to death than defendants of other races, while empirical studies of 14 states and the armed forces have found an even stronger effect on capital sentencing based on victims' race, concluding that those who kill White people are more likely to be sentenced to die than those who kill members of other racial and ethnic groups (see Cholbi and Madva 2018, notes 10, 11). These two effects also appear to interact, so that cases like McCleskey's “involving black defendants and white victims are treated more punitively than cases with all other defendant/victim racial combinations" (Baldus and Woodworth 2003). 
Can a case be made for the Movement for Black Lives' call for abolition on the basis of such evidence, even in the absence of proof that lawmakers, law enforcement officials, juries, etc. purposefully or intentionally discriminate against Black American defendants or victims in the capital punishment process? There is, we contend, conceptual space between purposeful discrimination and mere randomness or unpredictability, a space occupied by implicit bias. Before mapping this space, we stress that our claim is not that implicit bias alone explains the racial injustices of capital punishment. Implicit bias is just one factor among many. For example, some evidence suggests that due to tax cuts, local police departments have been increasingly pressured to devote greater resources to (i.e., overpolice) revenue-generating practices such as asset seizures and fines in Black American communities, which has forced them to devote fewer resources to (i.e., underpolice) preventing and solving violent crimes in those same communities (Goldstein, Sances, and You 2018). Such structural considerations are incredibly important. And we of course do not rule out the potential role of explicit bias in the devaluing and dehumanizing of Black lives (implicit and explicit forms of racial bias are, we believe, complexly intertwined; Madva 2019). Consider a recent study examining mock jurors' reactions to a case inspired by the shooting of Keith Scott in Charlotte in 2016 (Cooley, Lei, Brown-Iannuzzi, and Ellerkamp 2018). Researchers found that jurors' explicit racial prejudices negatively correlated with their willingness to attribute responsibility and guilt to an officer who fatally shot a Black (but not White) victim. Researchers also found that racial bias led jurors to perceive that the officer was in a "dangerous" or "threatening" situation when the victim was Black (but not White), and to deny that the officer's own racial biases could have been a factor in his decision-making. 
In what follows, however, we focus on implicit bias because, as we try to show, it poses unique constraints on which remedies will feasibly address the racial injustices at issue.

Cases like McCleskey unfolded at a time when overt endorsements of racial animosity were in decline yet broader patterns of racial discrimination persisted. Cleary, racism had not just vanished. Social psychologists thus began to develop a number of tools for detecting bias in contexts where individuals were either unable or unwilling to admit that they endorsed problematic racial stereotypes. Several decades on, it is clear that most Americans, including many African Americans, carry these implicit racial biases. ${ }^{3}$ Some of the most pernicious biases directly pertain to criminal justice, and an expanding body of research speaks to the specific role these biases play — consciously or unconsciously — in the perceptions, emotions, and decisions of eyewitnesses, police, prosecutors, judges, and juries (Nosek et al. 2007; Behrman and Davey 2001; Correll, Hudson, Guillermo, and Ma 2014; Glaser 2014; Ogletree, Smith, and Wald 2012; Smith and Cohen 2012; Spence, Charbonneau, and Glaser 2016). Moreover, while these biases surely exacerbate discrimination throughout the criminal justice system, they appear especially salient in capital sentencing contexts (Hunt 2015; Lynch and Haney 2011).

For example, Whites tend to be less sensitive to the pain experienced by Black people, which suggests that Black defendants, and the families of Black victims, can expect that prosecutors, judges, and juries will be less moved by their capacity to suffer (Trawalter, Hoffman, and Waytz 2016). In this vein, a field study found that jurors were less likely to report that the love, grief, and loss experienced by a victim's family played an important role in their decision-making when victims were Black than when White (Karp and Warshaw 2006). This insensitivity to

\footnotetext{
${ }^{3}$ For a review of "meaningful life outcomes" predicted by implicit attitudes, see Blair, Dasgupta, and Glaser (2015). For discussion of implicit bias measures in light of recent empirical criticisms, see Brownstein, Madva, and Gawronski (2019) and Brownstein, Madva, and Gawronski (Forthcoming).
} 
Black suffering is in turn likely explained by the tendencies to see Black people in some contexts as subhuman and primitive (Goff, Eberhardt, Williams, and Jackson 2008), and in other contexts as physically "superhuman” (Levinson 2007).

This dual tendency, toward the dehumanization and "superhumanization" of Black bodies, also helps to explain why Black people are likely to be perceived as more threatening and less amenable to rehabilitation. When defendants are Black, mock jurors are more likely to falsely remember "aggressive" details of a crime (Levinson 2007), and more likely to think that the conviction remains appropriate despite the use of inadmissible evidence (Hodson, Hooper, Dovidio, and Gaertner 2005; Johnson, Whitestone, Jackson, and Gatto 1995). ${ }^{4}$ Some studies tie these discriminatory patterns directly to implicit biases, some of which pose general problems for criminal justice, such as the automatic association of Black faces with words like "guilty" (Levinson, Cai, and Young 2010; Levinson and Young 2010), while others introduce specific problems for capital decision-making, such as the automatic association of Black people with words like "expendable" and "worthless" (Levinson, Smith, and Young 2014). This latter association was found to be especially prominent among mock jurors who were willing to convict regardless of a potential death sentence, and even predicted these individuals' decisions to sentence a Black defendant to death rather than life in prison. ${ }^{5}$ The implicit devaluation of

\footnotetext{
4 In fact, participants in Johnson Whitestone, Jackson, and Gatto (1995) falsely believed that they were less influenced by the inadmissible evidence when defendants were Black. For further studies on juror bias, see Cohn, Bucolo, Pride, and Sommers, 2009; Young, Levinson, and Sinnett, 2014.

${ }^{5}$ Researchers also found that the refusal to sentence someone to death led to the exclusion of non-White jurors, and that the death qualification process therefore exacerbated the impact of racial bias on capital sentencing. Notably, their participant sample was drawn from six of the most active death penalty states: Alabama, Arizona, California, Florida, Oklahoma, Texas. Moreover, "those who are more likely to be allowed to serve on death penalty cases are not only more likely to harbor racially prejudiced attitudes, but also are more likely to favor the conviction of innocent defendants over letting guilty ones go free.” (Young 2004); cf. Peffley and Hurwitz, 2002.
} 
Black defendants and victims in capital contexts may also illuminate why, when victims are White, defendants who look more stereotypically Black are also more likely to receive a death sentence (Eberhardt, Davies, Purdie-Vaughns, and Johnson 2006).

In fact, one study (Glaser, Martin, and Kahn 2015) found that Black and White defendants were equally likely to be convicted (67.7\% and $66.7 \%$ respectively) by mock jurors when life without parole was the maximum possible sentence, yet, when a death sentence was possible, conviction rates for White defendants fell (55.1\%) even as conviction rates for Black Americans rose $(80 \%)$. In other words, the sheer possibility of capital punishment may be a self-igniting engine of discrimination, over and above the more familiar influences of racial bias on decisions in other spheres. That capital punishment affords unique opportunities for bias to manifest is further supported by the finding that White support for the death penalty increases after White people learn about racial disparities in capital sentencing (Peffley and Hurwitz, 2007; cf. Hetey and Eberhardt, 2014).

We hypothesize that all the aforementioned implicit racial stereotypes and prejudices - the tacit devaluation of Black life, the insensitivity to Black pain and loss, and the impulses to see Black people as either superhuman threats or subhuman beings - make crimes committed by Black defendants (or against White victims) appear particularly heinous.

This research also makes it clear why existing reforms have largely failed to reduce racial discrimination in capital sentencing, and why the prospects for future reforms short of abolition are similarly grim. Take, for example, Matthew Kramer's recent proposal (2011, p. 245) that the death penalty be applied only in the most extreme, "defilingly evil" cases. Ordinarily, racial bias 
is indeed more likely to tip the scales in more ambiguous cases, ${ }^{6}$ which at first glance suggests that reserving the death penalty for the most morally unambiguous cases could bypass bias. But the evidence we just reviewed suggests that the ordinary rules do not apply in capital contexts: implicit biases make the murders committed by African Americans seem unambiguously grave, while the crimes committed against them seem decidedly less so. As a result, implementing proposals like Kramer's could well result in a disproportionate number of murders by Black Americans or murders of non-Black Americans to be classified as "defilingly evil" and so eligible for the death penalty.

Even if judges and jurors could somehow evade the influence of racial bias, and consistently recommended a death sentence only in extreme cases, this would still fail to address the insidious operations of bias prior to sentencing. Consider two examples. First, bias may affect the resources that detectives and prosecutors devote to gathering evidence, such that the evidence comes to seem more damning when victims are White. One study in Louisiana thus found that prosecutor case files were significantly thicker when victims were White women, and thinnest when victims were Black, which in turn correlated with severer sentences for those convicted of killing White people and women (Pierce, Radelet, Posick, and Lyman 2014). Implicit bias can, therefore, play a role in disambiguating cases. Second, consider the role of bias in voir dire. While most potential jurors explicitly report being unbiased, one study found that professional attorneys were nevertheless able to pick up on potential jurors' unstated racial biases, and keep or remove them from the pool partly on this basis (Morrison, DeVaul-Fetters, and Gawronski 2016). These decisions can, however, invariably be rationalized by appeal to ostensibly non-

\footnotetext{
${ }^{6}$ For example, mock jurors' implicit biases lead them to interpret ambiguous evidence as more damning when the defendant is dark-skinned than when light-skinned. See Levinson, Cai, and Young (2010) and Levinson and Young (2010).
} 
racial reasons (Sommers and Norton 2007). The operations of bias in this context are likely to persist unless attorneys are denied the right to strike jurors altogether. Both of these examples thus reveal the special challenges posed by implicit bias insofar as it is especially resilient in the face of attempted reforms, such as more precise sentencing guidelines or the requirement to consider both aggravating and mitigating factors. One of the most effective strategies for reducing the effects of bias is anonymization, the concealment of markers of racial identity during key decision-making moments. But anonymization is clearly not a viable option in these settings. ${ }^{7}$ Nor should we be optimistic that bias could be circumvented with seemingly more objective standards for use of the death penalty, such as having murdered multiple persons or mandatory use of the death penalty for all first-degree murders. ${ }^{8}$ Such standards would still leave many opportunities for racial bias to influence who is convicted of murder, such as in the evidence gathering and charging stages of the criminal justice process.

Post-conviction procedures such as mandatory appeals of all capital sentences have also been introduced as checks against arbitrariness in capital decisions. While such procedures may in principle be capable of reducing the total number of unjust death sentences, they may simultaneously introduce additional ways for racial bias to shape outcomes, insofar as sentence relief becomes more likely for White than Black defendants (Petrie and Coverdill 2010).

We believe that it is therefore established to a high degree of probability that structural unfairness pervades the criminal justice system such that Black Americans are discriminated against in cases in which capital punishment is a possible outcome, and that this discrimination is

\footnotetext{
${ }^{7}$ Though anonymization can be utilized in determining whether to charge individuals with crimes at all. See Williams (2019) for discussion of San Francisco's efforts to employ this strategy.

${ }^{8}$ Our co-editor Benjamin Yost suggested such a strategy. See also Cholbi and Madva (2018) and the PEA Soup blog discussion, Kelly et al. (2018).
} 
due in significant measure to implicit racial bias. Even if intentional or purposeful discrimination plays a minute role in such discrimination, this situation nevertheless cries out for reform. Failure to implement reform amounts to a reckless lack of concern for Black Americans' lives and liberties. Yet it is equally clear that mere procedural reforms are grossly insufficient for rooting out the systemic racial injustices in the capital punishment regime. Instead, given the evidence we have briefly reviewed here, it may very well be that abolishing the death penalty is itself one among several key steps necessary for reducing racial disparities in criminal justice more broadly.

$* * * * * * * * * * * * * * * * * * * * * * * * * * * * * * *$

The death penalty could be abolished in the U.S. de jure, through its legal prohibition, or de facto, through states retaining the death penalty in their sentencing statutes but effectively suspending its use. We contend that such abolition is the most reasonable reform in light of the role that implicit bias plays in generating the racial discrimination at issue. As noted earlier, that implicit bias plays a prominent role in generating these discriminatory patterns casts serious doubt on whether procedural reforms could ever be adequate to diminish or eliminate these patterns.

Any defensible reform must diminish or eliminate such discrimination. Abolition of capital punishment, we propose, is the only reform likely to be both effective and minimally just. Again, procedural reforms would likely be ineffective. As we have indicated, the bias at issue intercedes at multiple points in the processes that can lead to capital sentences: in investigative practices, in prosecutorial decisions, in courtroom behaviors, in jury selection, in sentencing, etc. Law and legal institutions can of course be better or worse at filtering out different biases. In this case, 
however, there are grounds for skepticism that procedural reforms will do much to ferret out the bias in question. In addition, any move to tighten the standards for capital sentences will run the risk of diminishing the discretion of actors within these institutions, discretion that allows for cases to be adjudicated on the basis of specific facts about crimes, defendants' histories, etc.

No doubt enthusiasts for capital punishment will view our proposal as morally costly: If the death penalty is abolished, then presumably those guilty of the most serious crimes (murder predominantly) would be sentenced to the next most severe punishment (in all likelihood, life imprisonment without possibility of parole). If death is the only deserved punishment for such crimes, then abolition would result in many criminals not getting what they deserve. For some defenders of capital punishment, such as Ernest van den Haag, racial discrimination in capital charging, trials, sentencing, etc., can never be a sufficiently serious moral cause to outweigh this loss. Van den Haag remarks:

If and when discrimination occurs it should be corrected. Not, however, by letting the guilty blacks escape the death penalty because guilty whites do, but by making sure that the guilty white offenders suffer it as the guilty blacks do. Discrimination must be abolished by abolishing discrimination - not by abolishing penalties. However, even if...this cannot be done, I do not see any good reason to let any guilty murderer escape his penalty. It does happen in the administration of criminal justice that one person gets away with murder and another is executed. Yet the fact that one gets away with it is no reason to let another one escape. (van den Haag and Conrad 1983, p. 223)

Admittedly, we have not suggested here that death is in principle an unjust penalty for certain very severe crimes such as murder. Indeed, we have granted as much for the sake of argument. We allow the possibility that a community with a very different racial history than that found in the U.S. could implement the death penalty in a non-discriminatory fashion, and on the assumption that the death penalty is in principle a just punishment, that would not be a morally objectionable outcome. Yet we do not share van den Haag's insistence that discrimination may 
only be rightfully addressed by abolishing discrimination without abolishing penalties. That racial discrimination in the U.S. capital punishment regime is traceable in part to implicit bias suggests that in this instance at least we may be unable to 'abolish' discrimination. Moreover, even if death is a just punishment for certain severe crimes, that it is uniquely just as a punishment for such crimes is a stronger and more dubious claim. There is no obvious basis for assuming a one-to-one correspondence between a crime with a specific moral gravity and a punishment of proportional severity (that, e.g., only death and not life incarceration without parole is a just punishment for murder). We doubt that the geometry of desert is so precise or that our judgments about that geometry should be uncritically relied upon. If desert should govern how we punish, then certainly it can be unjust not to subject those guilty of egregious crimes to severe punishments. But we should not overlook that life imprisonment is itself an extremely serious punishment, involving a wide range of physical and mental suffering as well as wholesale deprivations of liberty and opportunity. (Indeed, considerations like these lead some in the Movement for Black Lives to advocate the abolition of punishment altogether. Addressing their broader concerns about the criminal justice system is beyond the scope of this chapter, but see Davis 2003 and Yost, this volume.) The gap, then, between the severity of death and the severity of life imprisonment is narrower than it appears. Abolition of the death penalty would result in the effective commutations of a few thousand prisoners currently on death row to life sentences (NAACP Legal Defense and Education Fund 2016), as well as resulting in about 40 additional life sentences (rather than executions) per year (Death Penalty Information Center 2017). Given the small numbers of offenders involved and the small gap in severity between execution and life imprisonment, the moral costs of abolishing capital punishment that vex van den Haag are more modest than they appear at first glance. 
A final consideration in favor of abolition is this: van den Haag (and many others) assume that the only reasons we might have to favor abolition out of concern for racial discrimination are those flowing from the unjust treatment of Black American defendants or Black American murder victims. This overlooks, however, that racial discrimination in capital charging and sentencing is not only an injustice to those particular Black Americans that engage with the U.S. capital sentencing regime. As the Movement's platform states, such discrimination also represents a political wrong done to Black Americans as a class.

To see why, return again to the issue of police shootings of Black American suspects. The most obvious victims of such wrongful shootings are those injured or killed by police in such incidents (as well as their families, friends, communities, etc.). But the pattern of such shootings also has moral consequences that extend beyond the shootings themselves. Parents of Black American children often feel compelled to have 'the talk' with their children, dispensing advice about how to engage with police officers so as to prevent themselves being subjected to police harassment or violence (Pittman 2017). That parents feel the need to dispense such advice is an indication that police shootings establish a different relationship between Black Americans and law enforcement than is found between law enforcement and other racial or ethnic groups. For Black Americans, that relationship is more materially fraught, posing a greater risk of harassment or violence. But that relationship is also morally fraught. For Black Americans have good reason to believe that law enforcement does not accord them same respect or status as other citizens enjoy. The mistreatment found in police shootings thus extends beyond those Black Americans who are criminal suspects or who are directly mistreated by police. Rather, each and every Black American, insofar as she can expect a greater probability of such mistreatment 
should she encounter the police as a suspect, is not accorded the same respect or status as other citizens, even if such encounters never in fact occur. The majority of Black Americans will never be criminal suspects or have a confrontation with police, yet they know where they stand with respect to their treatment by police, namely, that police are more likely not to show the same restraint they show toward citizens of other races.

Police shootings, therefore, alter the moral nature of the relationship between Black Americans and law enforcement, to wit, such relationships embody a lack of equal respect or ascription of equal status to Black Americans. This is an injustice separate from, and arguably far greater in scope, than the injustices done to particular victims of police victims. There is a parallel injustice that arises with respect to racial discrimination related to capital crimes. Particular Black Americans suffer retributive injustices in the US capital punishment regime when they are sentenced to die in part due to their race or when those that murder Black Americans avoid the death penalty because of their victims' Black race. But Black Americans as a class also suffer distributive injustice under that regime. More specifically, Black Americans do not receive either the equal protection of, or equal status under, the law. They do not enjoy equal status under the law because they face an increased likelihood of suffering a greater cost than others would due to factors (i.e., race) unrelated to objective desert. A fair system of justice would not effectively threaten greater sanctions, all other things being equal, for Black Americans who murder than it threatens toward members of other racial groups. This unfairness is one to which all Black Americans, not merely Black American murderers murder suspects, face. At the same time, Black Americans do not enjoy equal protection of the law under a capital sentencing regime that threatens greater sanctions, all other things, for those who murder nonBlack Americans than for those who murder Black Americans. Again, this unfairness is one to 
which all Black Americans, not merely Black American murder victims or their families, face.

On our analysis then, the Black American community is mistreated by the American capital punishment regime because that regime makes it the case that two crucial political goods the legal system is responsible for 'distributing' are unjustly distributed on the basis of race. Black American murder defendants are not extended the same legal status as other defendants; they are presumed less innocent than defendants of other racial groups. Black American victims of murder are not extended the same legal protection as victims of other races; their killers are presumed more innocent than those who kill members of other racial groups. The injustices wrought by racial bias in American capital sentencing extend beyond the specific retributive wrongs done to Black American murder suspects or murder victims. The injustices thus extend to the Black American community as a whole, because the capital sentencing regime generates normative realities in which Black Americans are not treated as equals (much as the injustice of police shootings extends beyond the particular shooting victims to the Black American community as a whole).

That there is an additional distributive injustice at issue here strengthens the case for abolition as the most defensible reform in light of racial discrimination in capital cases. Contra van den Haag and others, there is an additional "good reason" to abolish the death penalty independent of retributive considerations concerning which offenders receive it and which do not. That abolition would help to place 39 million Black Americans on more equal footing with other Americans as far as the respect and status the criminal justice system accords them is a powerful reason in its favor. Only abolition, we contend, would do this, and would come at a moral cost (foregoing executions) that appears modest in comparison. 
Much of American jurisprudence, and academic argumentation surrounding race and capital punishment, have therefore been mistaken about the sources of racial discrimination in the American capital punishment regime. That implicit racial bias, instead of overt acts of discrimination, is a key source of such discrimination implies that abolition is likely to be the only adequate remedy for such discrimination. The Movement for Black Lives' call for death penalty abolition because it wrongs Black American communities highlights how the best rationale for abolition has also not been appreciated. That such discrimination constitutes a wrong not simply to Black Americans who engage with the capital punishment regime either as defendants or as murder victims but also to Black Americans as a class insofar as they not accorded equal respect under, or the equal status of, the law, implies that abolition is a remedy for a wrong of noticeably greater magnitude than extant discussions of such matters have recognized. Together, these two factors ground a stronger case for the abolition of capital punishment on the grounds of comparative justice than has been heretofore been elucidated. 


\section{REFERENCES}

Alexander, M. (2010) Interview, Bill Moyers' Journal. [Online]. Available at http://www.pbs.org/moyers/journal/04022010/transcript1.html (Accessed 21 March 2017)

Baldus, D.C., Pulaski, C. and Woodworth, G. (1983). 'Comparative review of death sentences: An empirical study of the Georgia experience.' Journal of Criminal Law and Criminology 72, pp. $661-753$.

Baldus, D.C. and Woodworth, G. (2003). 'Race discrimination in the administration of the death penalty: An overview of the empirical evidence with special emphasis on the post-1990 research.' Criminal Law Bulletin 39, pp. 194-226.

Batson v. Kentucky, 476 U.S. 79 (1986).

Behrman, B.W. and Davey, S.L. (2001). 'Eyewitness identification in actual criminal cases: An archival analysis.' Law and Human Behavior 25, pp. 475-491.

Blair, I., Dasgupta, N., and Glaser, J. (2015). 'Implicit attitudes.' In Mikulincer, M., Shaver, P.R., Borgida, E., and Bargh, J.A. (eds.) APA Handbook of Personality and Social Psychology, Volume 1: Attitudes and Social Cognition. Washington, American Psychological Association, pp. $665-691$.

Brownstein, M., Madva, A., and Gawronski, B. (2019). 'What do implicit measures measure?' Wiley Interdisciplinary Reviews: Cognitive Science 1-13. https://doi.org/10.1002/wcs.1501 Brownstein, M., Madva, A. and Gawronski, B. (Forthcoming) 'Understanding implicit bias: Putting the criticism into perspective.' Pacific Philosophical Quarterly.

Cholbi, M. (2006). 'Race, capital punishment, and the cost of murder.' Philosophical Studies 127 (2), pp. 255-82. https://doi.org/10.1007/s11098-005-4958-6.

Cholbi, M., and Madva, A. (2018). 'Black Lives Matter and the call for death penalty abolition.' 
Ethics, 128(3), pp. 517-44. https://doi.org/10.1086/695988

Cohn, E.S., Bucolo, D., Pride, M., and Sommers, S.R. (2009). 'Reducing white juror bias: The role of race salience and racial attitudes.' Journal of Applied Social Psychology 39, pp. 19531973. https://doi.org/10.1111/j.1559-1816.2009.00511.x.

Cooley, E., Lei, R., Brown-Iannuzzi, J., and Ellerkamp, T. (2018). 'Personal prejudice, other guilt: Explicit prejudice toward Black people predicts guilty verdicts for white officers who kill Black men.' Personality and Social Psychology Bulletin 45(5), pp. 754-766. https://doi.org/10.1177/0146167218796787

Correll, J., Hudson, S.M., Guillermo, S., and Ma, D.S. (2014). 'The police officer's dilemma: A decade of research on racial bias in the decision to shoot.' Social and Personality Psychology Compass 8, pp. 201-213. https://doi.org/10.1111/spc3.12099.

Davis, A.Y. (2003). Are prisons obsolete? Seven Stories Press.

Death Penalty Information Center. (2017). Fact Sheet, March 20, 2017. [Online] http://www.deathpenaltyinfo.org/documents/FactSheet.pdf. Retrieved 30 March 2017.Eberhardt, J.L., Davies, P.G., Purdie-Vaughns, V.J., and Johnson, S.L. (2006). 'Looking deathworthy: Perceived stereotypicality of Black defendants predicts capital-sentencing outcomes.' Psychological Science 17, pp. 383-386. https://doi.org/10.1111/j.1467-9280.2006.01716.x. Furman vs. Georgia. 408 U.S. 238 (1972)

Glaser, J. (2014). Suspect race: Causes and consequences of racial profiling. Oxford University Press.

Glaser, J., Martin, K.D., and Kahn, K.B. (2015). 'Possibility of death sentence has divergent effect on verdicts for Black and White defendants.' Law and Human Behavior 39, pp. 539-546. https://doi.org/10.1037/lhb0000146. 
Goff, P.A., Eberhardt, J.L., Williams, M.J., and Jackson, M.C. (2008). 'Not yet human: Implicit knowledge, historical dehumanization, and contemporary consequences.' Journal of Personality and Social Psychology 94, pp. 292-306. https://doi.org/10.1037/0022-3514.94.2.292

Goldstein, R., Sances, M.W. and You, H.Y. (2018). 'Exploitative revenues, law enforcement, and the quality of government service.' Urban Affairs Review.

https://doi.org/10.1177/1078087418791775

Gregg v. Georgia. 428 U.S. 153 (1976).

Hetey, R.C. and Eberhardt, J.L. (2014). 'Racial disparities in incarceration increase acceptance of punitive policies.' Psychological Science 25, pp. 1949-1954.

https://doi.org/10.1177/0956797614540307

Hodson, G., Hooper, H., Dovidio, J.F., and Gaertner, S.L. (2005). 'Aversive racism in Britain: the use of inadmissible evidence in legal decisions.' European Journal of Social Psychology 35, pp. 437-448. https://doi.org/10.1002/ejsp.261

Hunt, J.S. (2015). 'Race, ethnicity, and culture in jury decision making.' Annual Review of Law and Social Science 11, pp. 269-288. https://doi.org/10.1146/annurev-lawsocsci-120814-121723. James, J. (2000). 'The dysfunctional and the disappearing: Democracy, race and imprisonment.' Social Identities 6(4), pp. 483-92. https://doi.org/10.1080/13504630020026422. Johnson, J.D., Whitestone, E., Jackson, L.A., Gatto, L. (1995). 'Justice is still not colorblind: Differential facial effects of exposure to inadmissible evidence. Personality and Social Psychology Bulletin 21, pp. 893-898. https://doi.org/10.1177/0146167295219003 Karp, D.R. and Warshaw, J.B. (2006). 'Their day in court: The role of murder victims' families in capital juror decision making.' In Acker, J.R. and Karp, D.R. (eds.), Wounds that do not bind: Victim-based perspectives on the death penalty. Carolina Academic Press, Durham, NC, pp. 275- 
295.

Kelly, E., et al. (2018) 'Ethics Discussion at PEA Soup: Michael Cholbi and Alex Madva's, "Black Lives Matter and the Call for Death Penalty Abolition," with a critical précis by Erin Kelly,' PEA Soup blog. [Online]. http://peasoup.us/2018/04/ethics-discussion-at-pea-soupmichael-cholbi-and-alex-madvas-black-lives-matter-and-the-call-for-death-penalty-abolitionwith-a-critical-precis-by-erin-kelly/.

Kramer, M. (2011). Ethics of capital punishment. Oxford University Press.

Levinson, J. (2007). 'Forgotten racial equality: Implicit bias, decisionmaking, and misremembering.' Duke Law Journal 57, pp. 345-424.

Levinson, J.D., Cai, H., and Young, D. (2010). 'Guilty by implicit racial bias: The guilty/not guilty implicit association test.' Ohio St. Journal of Criminal Law 8, pp. 187-208.

Levinson, J.D., Smith, R.J., and Young, D.M. (2014). 'Devaluing death: An empirical study of implicit racial bias on jury-eligible citizens in six death penalty states.' N.Y.U. Law Review 89(2), pp. 513-581.

Levinson, J.D. and Young, D. (2010). 'Different shades of bias: Skin tone, implicit racial bias, and judgments of ambiguous evidence.' West Virginia Law Review 112, pp. 307-350.

Lynch, M., and Haney, C. (2011). 'Looking across the empathic divide: Racialized decision making on the capital jury.' Michigan State Law Review 2011, pp. 573-607

Madva, A. (2019). 'Social Psychology, Phenomenology, and the Indeterminate Content of Unreflective Racial Bias.' In Lee, E.S. (Ed.), Race as Phenomena: Between Phenomenology and Philosophy of Race. Rowman \& Littlefield International: Lanham, pp. 87-106. McCleskey v. Kemp, 481 U.S. 279 (1987).

Miller-El v. Dretke, 545 U.S. 231 (2005). 
Morrison, M., DeVaul-Fetters, A., and Gawronski, B. (2016). 'Stacking the jury: Legal

professionals peremptory challenges reflect jurors' levels of implicit race bias.' Personality and Social Psychology Bulletin 42, pp. 1129-1141. https://doi.org/10.1177/0146167216651853

Movement for Black Lives Platform. (2017). End the war on Black people. [Online]. Available at https://policy.m4bl.org/end-war-on-black-people/ (Accessed 6 Mar 2017)

Muhammad, K.G. (2010). The condemnation of Blackness: Race, crime, and the making of modern urban America. Cambridge: Harvard University Press.

Myrdal, G. (1944). An American dilemma: The Negro problem and modern democracy. New York: Harper.

NAACP Legal Defense and Educational Fund. (2016). "Death Row U.S.A. Summer 2016," July 1, 2016. [Online] http://www.naacpldf.org/files/publications/DRUSA_Summer_2016.pdf. Accessed 30 March 2017.

Nosek, B.A., Smyth, F.L., Hansen, J.J., Devos, T., Lindner, N.M., Ranganath, K.A., Smith, C.T., Olson, K.R., Chugh, D., Greenwald, A.G., and Banaji, M.R. (2007). 'Pervasiveness and correlates of implicit attitudes and stereotypes.' European Review of Social Psychology 18, pp. 36-88. https://doi.org/10.1080/10463280701489053.

Ogletree, C., Smith, R.J., and Wald, J. (2012). 'Coloring punishment: Implicit social cognition and criminal justice.' In Levinson, J.D., and Smith, R.J. (eds.), Implicit racial bias across the law. Cambridge: Cambridge University Press, pp. 45-60.

Peffley, M., and Hurwitz, J. (2007). 'Persuasion and resistance: Race and the death penalty in America.' American Journal of Political Science 51, pp. 996-1012.

https://doi.org/10.1111/j.1540-5907.2007.00293.x.

Peffley, M., and Hurwitz, J. (2002). 'The racial components of "race-neutral” crime policy 
attitudes.' Political Psychology 23, pp. 59-75. https://doi.org/10.1111/0162-895X.00270.

Petrie, M.A. and Coverdill, J.E. (2010). 'Who lives and dies on death row? Race, ethnicity, and post-sentence outcomes in Texas.' Social Problems 57, pp. 630-652.

Pierce, G.L., Radelet, M.L., Posick, C., and Lyman, T. (2014). 'Race and the construction of evidence in homicide cases.' American Journal of Criminal Justice 39, pp. 771-786.

Phillips, S. (2008). 'Racial disparities in the capital of capital punishment.' Houston Law Review 45, pp. 807-840.

Pittman, T. (2017). 'Inside the heartbreaking talk Black parents must have with their kids.' Huffington Post, 4 November 2016/ [Online] http://www.huffingtonpost.com/entry/inside-theheartbreaking-talk-black-parents-must-have-with-their-kids_us_581ca092e4b0d9ce6fbb465b Accessed 30 March 2017.

Smith, R.J., and Cohen, G.B. (2012). 'Choosing life or death (implicitly).' In Levinson, J.D., and Smith, R.J. (eds.), Implicit racial bias across the law. Cambridge: Cambridge University Press, pp. 229-243.

Snyder v. Louisiana, 552 U.S. 472 (2008).

Sommers, S.R., and Norton, M.I. (2007). 'Race-based judgments, race-neutral justifications: Experimental examination of peremptory use and the Batson challenge procedure'. Law and Human Behavior 31, pp. 261-273. https://doi.org/10.1007/s10979-006-9048-6

Spencer, K.B., Charbonneau, A.K., and Glaser, J. (2016). 'Implicit bias and policing'. Social and Personality Psychology Compass 10, pp. 50-63. https://doi.org/10.1111/spc3.12210.

Trawalter, S., Hoffman, K.M., and Waytz, A. (2016). 'Correction: Racial bias in perceptions of others' pain.' PLOS ONE 11, e0152334. https://doi.org/10.1371/journal.pone.0152334. Van den Haag, and Conrad, J.P. (1983). The death penalty: a debate. New York: Springer. 
Waytz, A., Hoffman, K.M., and Trawalter, S. (2015). 'A superhumanization bias in Whites' perceptions of Blacks.' Social Psychological and Personality Science 6, pp. 352-359. https://doi.org/10.1177/1948550614553642.

Williams, T. (2019) 'Black people are charged at a higher rate than Whites. What if prosecutors didn't know their race?" The New York Times, June 12, 2019. [Online] https://www.nytimes.com/2019/06/12/us/prosecutor-race-blind-charging.html. (Accessed 14 Jul 2019)

Yost, B. (2020). 'Leniency for black offenders.' In Cholbi, M., Hogan, B., Madva, A., and Yost, B. (eds.) The Movement for Black Lives: Philosophical Perspectives. Oxford University Press. Young, D.M., Levinson, J.D., and Sinnett, S. (2014). 'Innocent until primed: Mock jurors' racially biased response to the presumption of innocence.' PLOS ONE 9, e92365. https://doi.org/10.1371/journal.pone.0092365 Young, R.L. (2004). 'Guilty until proven innocent: Conviction orientation, racial attitudes, and support for capital punishment.' Deviant Behavior 25, pp. 151-167.

https://doi.org/10.1080/01639620490266916 